NBER WORKING PAPER SERIES

\title{
IS A DONOR IN HAND BETTER THAN TWO IN THE BUSH? EVIDENCE FROM A NATURAL FIELD EXPERIMENT
}

\author{
Craig E. Landry \\ Andreas Lange \\ John A. List \\ Michael K. Price \\ Nicholas G. Rupp \\ Working Paper 14319 \\ http://www.nber.org/papers/w14319 \\ NATIONAL BUREAU OF ECONOMIC RESEARCH \\ 1050 Massachusetts Avenue \\ Cambridge, MA 02138 \\ September 2008
}

We are grateful to Jamie Brown-Kruse for working with us in her capacity as the Director of the Hazard Center. We thank the Editor and three anonymous referees for excellent insights that markedly improved the study. Colin Camerer, Ernst Fehr, Glenn Harrison, Lise Vesterlund, and seminar participants at several universities, conferences, and meetings also provided useful insights. The views expressed herein are those of the author(s) and do not necessarily reflect the views of the National Bureau of Economic Research.

(C) 2008 by Craig E. Landry, Andreas Lange, John A. List, Michael K. Price, and Nicholas G. Rupp. All rights reserved. Short sections of text, not to exceed two paragraphs, may be quoted without explicit permission provided that full credit, including $\odot$ notice, is given to the source. 
Is a Donor in Hand Better than Two in the Bush? Evidence from a Natural Field Experiment Craig E. Landry, Andreas Lange, John A. List, Michael K. Price, and Nicholas G. Rupp NBER Working Paper No. 14319

September 2008

JEL No. C93,H41,Q5

\title{
ABSTRACT
}

This study develops theory and conducts an experiment to provide an understanding of why people initially give to charities, why they remain committed to the cause, and what factors attenuate these influences. Using an experimental design that links donations across distinct treatments separated in time, we present several insights. For example, we find that previous donors are more likely to give, and contribute more, than donors asked to contribute for the first time. Yet, how these previous donors were acquired is critical: agents who are initially attracted by signals of charitable quality transmitted via an economic mechanism are much more likely to continue giving than agents who were initially attracted by non-mechanism factors.

\author{
Craig E. Landry \\ East Carolina University \\ landryc@ecu.edu \\ Andreas Lange \\ University of Maryland \\ alange@arec.umd.edu \\ John A. List \\ Department of Economics \\ University of Chicago \\ 1126 East 59th \\ Chicago, IL 60637 \\ and NBER \\ jlist@uchicago.edu
}

Michael K. Price

University of Nevada, Reno

mprice@cabnr.unr.edu

Nicholas G. Rupp

East Carolina University

ruppn@ecu.edu 
Charitable giving has historically been linked to religious activities. Dating at least to ancient Egypt, religious gifts were believed to ensure a just reward in the afterlife. More recently, tithing has become the traditional philanthropic ideal of Christianity, wherein one-tenth of a person's income is expected to be contributed to charity. ${ }^{1}$ Yet, charitable fund-raising has taken on a much broader role in the past several centuries. In the Western world, near the mid-1800s, it was recognized that individuals and corporations could play a part in financing non-profit agencies with the introduction of new fund-raising techniques. The most innovative techniques can be traced to the Young Men's Christian Association, an organization founded in London in 1844 as a response to unhealthy social conditions arising near the end of the Industrial Revolution. ${ }^{2}$

Numerous non-profit agencies quickly followed, setting in motion the vibrant industry of today. In the US alone, the American Association of Fundraising Counsel estimates that annual giving now exceeds 2 percent of GDP. Increased individual wealth, an aging population, and recent devolutionary trends across governments worldwide combine to set the stage for continued rapid growth in the sector. This presents fundraisers, who typically rely on rules of thumb rather than hard scientific evidence, with a unique opportunity. Most commentators, however, view the industry as lacking an appropriate understanding of the economic underpinnings to take full advantage of this prospect. Fund-raising consultant Tony Kneer (The Economist, July 29 ${ }^{\text {th }}$ 2004) highlights this belief by noting that "There is an extraordinary amount of money available. The lack is of good ideas on how to get the basket under the apple tree.”

\footnotetext{
${ }^{1}$ Of course, charity is important in other religions such as Islam, Judaism, and Buddhism.

${ }^{2}$ The new approach to fund-raising put forth by the Young Men's Christian Association-intensive drives over a short period of time using quite sophisticated techniques—-was followed by solicitees during World War I, leading to the creation of the United Way.
} 
Accentuating this reality is the fact that even though there has been a tremendous amount of new research, even the primitives of the economics of charity remain ill-understood.

Before one can begin to advance potential solutions as to the most efficient means to attract and maintain donors to finance public goods, one must understand the basics of giving. Even though the economics of charity has been well studied on the "supply" side (see, e.g., Charles Clotfelter, 1985; William Randolph, 1995; John Peloza and Peirs Steel, 2005), critical gaps remain on the "demand" side (James Andreoni, 2006). In this regard, fund-raisers have developed a variety of strategies aimed at successfully reaching specific funding targets, but little systematically is known about (i) what induces donors to give in the first place, (ii) what causes them to remain committed to the cause, and (iii) what factors attenuate these influences. Answers to such questions are important not only to further our understanding of what theoretical models best predict behavior, but also from a public policy and practical viewpoint.

The first goal of this study is to provide a theoretical foundation of charitable giving that examines how a donor's historical interactions with a charitable organization influence contribution decisions. The model provides a theoretical rationale to explain why previous donors are more likely to contribute in future campaigns, and outlines factors that may serve to attenuate such loyalty. Importantly, the model highlights an asymmetry in the long-run effects of mechanism versus non-mechanism incentives. ${ }^{3}$ The model also provides an explanation for why the appeal mode, for example door-to-door and mail solicitation, might be critically important.

\footnotetext{
${ }^{3}$ For convenience, we denote "mechanism" effects as the choice of announcing seed money, using matching grants, using lotteries or auctions. We denote "non-mechanism" effects as factors that are not related to economic institutional choice, such as the use of certain solicitor types.
} 
A second goal of the study is to test the implications of the model. Because our theory relies on a firm understanding of the temporal profile of previous gifts, it is important to use an approach whereby we can adequately control for the distribution of previous donors. This calls for a field experiment with a relatively new charity that randomized previous donors into various treatment cells, and therefore has detailed information on all previous gifts and knowledge of what factors initially attracted donors.

In this spirit, it is natural to organize a capital campaign for the Center for Natural Hazards Research at East Carolina University (ECU). The Hazard Center was authorized to begin operations in the fall of 2004 by the North Carolina state government; importantly, there has been only one previous fund-raiser for the Center, a door-to-door fund-raising drive which took place in late 2004, which randomized donors into various treatment cells (see Landry et al., 2006). For our purposes, the most important insights from Landry et al. (2006) are that linking contributions with the chance of winning a lottery prize and the physical appearance of female solicitors both influenced giving to the Hazard Center dramatically.

In designing our field experiment, we make use of detailed information on the households that were previously approached and how they were approached. The fundraising effort used to test our theory is centered on a door-to-door drive, but we also provide suggestive insights from a small-scale mail solicitation. Both campaigns took place in the late spring/early summer of 2006. We designed the campaigns to test our theory while maintaining the naturalness of each particular solicitation. We randomly allocated previous givers ("warm” list subjects) and those who have never given (“cold" list subjects) into one of three treatments: a standard voluntary contributions mechanism 
(VCM—simply asking solicitees for money) and two gift treatments—asking solicitees for money, but giving a large or a small gift to the potential donors. Our approach can therefore go beyond typical efforts in the literature since we are able to examine the dynamics of charitable fund-raising. ${ }^{4}$

Some interesting insights emerge that are consonant with our theory. First, the warm-list enhances fund-raising success in the VCM door-to-door treatment: donors who contributed in the first fund-raising drive are 19 percent more likely to give to the Hazards Center and provide average gifts that are roughly twice as large as households that have never given. Yet, when we provide potential donors with gifts, behavior of warm list agents is statistically indistinguishable from that of cold list agents. Thus, a donor in hand is better than two in the bush provided the mechanism used is a standard "simply ask for money," or VCM. When a solicitor has access to gifts for potential contributors, however, two donors in the bush are preferred to one donor in hand because in these treatments cold and warm list agents behave similarly.

Second, we find a fundamental difference in the efficacy of prior mechanism and non-mechanism factors in our follow-up campaign. Removing a mechanism incentive has no discernable impact on the behavior of warm-list households whereas removing non-mechanism factors leads to a reduction in average contribution levels from such households. This result is consonant with the initial mechanism incentive providing an

\footnotetext{
${ }^{4}$ Recent fundraising studies that explore mechanism effects include the work on the efficacy of matching funds (e.g., Yan Chen et al., 2006; Dean Karlan and List, 2007; Stephan Meier, 2007), seed money announcements (e.g., List and David Lucking-Reiley, 2002), and lotteries (e.g., John Morgan 2000; Landry et al. 2006; Lange et al. 2007). None of these studies attempt to explore long run effects of giving, except Meier (2007), who finds that in the long run those who received the match give less than the control group. Although not a study in the spirit of these mechanisms, Jen Shang and Rachel Croson (2007) also explore the amounts individuals give over time.
} 
enduring signal of charitable quality. In this case, a donor in hand is better than two in the bush provided the mechanism that first attracted the donor transmitted a signal that enhanced charitable quality.

Finally, we find that the loyalty of previous donors is attenuated when we change the appeal mode. While warm-list households that originally gave in a door-to-door campaign are more likely to donate in a subsequent mail solicitation than a randomly selected individual, the noisiness of the data precludes strong inference. Comparing rates of giving and gift sizes across our two campaigns yields a data pattern that is consistent with several models, including one whereby social pressure is an important factor influencing solicitees. Overall, these results highlight the potential usefulness of moving beyond an experimental design that focuses on short run substitution effects, and provide a deeper understanding of which theoretical models best predict donor behavior.

The remainder of our study proceeds as follows. The next section provides the theoretical framework on which we base our field experiment. Section III describes our field experimental design. Section IV summarizes our findings and Section V concludes.

\section{Theoretical Model}

To provide direction to our field experimental design, we extend the models presented in Andreoni $(1989,1990)$ and Landry et al. (2006) to account for historical interactions with the charity. A key feature of our model is that it incorporates a composite utility component, whose realization may depend upon both the interpersonal interaction between potential donor and solicitor and the fund-raising method.

We model an agent $i \in \Omega$ whose utility is additively separable into utility $u_{i}$ from

consuming a numeraire good, $y_{i}$, utility $\theta h_{i}(G)$ from a public good provided at some 
aggregate level $G$, and a composite utility term, $f_{i}(\bullet)$. Throughout, we assume that $h_{i}(\bullet)$ is increasing and concave and that $\theta \in\{0,1\}$ reflects whether the charity is of high ( $\theta=1$ ) or low $(\theta=0)$ quality. The composite utility term is multidimensional, including both a warm glow component as well as a disutility of not giving.

We allow each of these three utility components to depend on the current fundraising mechanism $M_{c}$ employed by the charity. $M_{c}$ encompasses both the institution utilized and the mode of appeal (door-to-door or mail solicitation), and therefore the interpersonal interaction. In particular, we allow that interpersonal interactions can influence both the shape and magnitude of $f_{i}(\bullet) .^{5}$ This term therefore implicitly includes both the extent to which a donor's actions are observed and the characteristics of the solicitor observing such actions.

We assume that agents have incomplete information regarding the true value of the public good but attach a probability $\mu_{i} \in[0,1]$ that the charity is of high quality-i.e., $\theta h_{i}(G)=h_{i}(G) .{ }^{6}$ As discussed in Lise Vesterlund (2003), a charity can gain credibility and thereby increase $\mu_{i}$ by using mechanisms $\left(M_{c}\right)$ that provide credible signals of charitable quality. Such approaches include the provision of matching funds/gifts to potential donors or the announcement of seed money and lottery prizes. ${ }^{7}$ Intuitively, we expect this effect to depend on both the current and previous interactions between

\footnotetext{
${ }^{5}$ In many regards, our composite utility term generalizes the "moral" component of utility discussed in Steven D. Levitt and List (2007). Importantly the definition of our composite utility term allows decisions to vary based on the extent to which actions are scrutinized by expectant others.

${ }^{6}$ Note that $\mu_{i} \in[0,1]$ thereby coincides with the expected value of $\theta\left(\mu_{i}=\mu_{i} 1+\left(1-\mu_{i}\right) 0\right)$. In the following, we therefore base the discussion on $\mu_{i}$ only.

${ }^{7}$ Andreoni (1998) discusses a different effect of seed money: seed money in his model provides a device to eliminate zero-contribution equilibrium in a threshold public good game.
} 
solicitee and charity—i.e., both the current $M_{c}$ and any previously used fund-raising mechanisms, $M_{p}$, are expected to affect the instantaneous realization of $\mu_{i}=\mu_{i}\left(M_{c}, M_{p}\right)$.

In choosing her donation level $b_{i}$, agent $i$ derives utility according to:

$$
V_{i}=u_{i}\left(y_{i}\left(b_{i} ; M_{c}\right)\right)+\mu_{i}\left(M_{c}, M_{P}\right) h_{i}(G)+f_{i}\left(b_{i} ; M_{c}\right)
$$

In our model, numeraire consumption, is determined by the budget of the agent, $y_{i}\left(b_{i} ; M_{C}\right)=w_{i}-b_{i}+R_{i}\left(b_{i} ; M_{C}\right)$, where $R_{i}\left(b_{i} ; M_{C}\right)$ denotes any potential private monetary or consumption benefits conveyed by a particular fund-raising drive. Finally, we assume that $f_{i}(\bullet)$ is concave in $b_{i}$ and both $u_{i}(\bullet)$ and $h_{i}(\bullet)$ are (strictly) increasing and concave.

Agent $i$ selects a contribution level to maximize utility and contributes a positive amount if

$$
u_{i}^{\prime}\left(y_{i}\left(0 ; M_{C}\right)\right) \frac{\partial}{\partial b_{i}} y_{i}\left(0 ; M_{C}\right)+\mu_{i}\left(M_{C}, M_{P}\right) h_{i}^{\prime}\left(G_{-i}\right)+\frac{\partial}{\partial b_{i}} f_{i}\left(0 ; M_{C}\right)>0
$$

at $b_{i}=0$ and contributes zero otherwise. Assuming an interior solution, the agent maximizes utility by selecting a contribution level $b_{i}^{*}$ that satisfies the following firstorder condition:

$$
u_{i}^{\prime}\left(y_{i}\left(b_{i}^{*} ; M_{C}\right)\right) \frac{\partial}{\partial b_{i}} y_{i}\left(b_{i}^{*} ; M_{C}\right)+\mu_{i}\left(M_{C}, M_{P}\right) h_{i}^{\prime}\left(G^{*}\right)+\frac{\partial}{\partial b_{i}} f_{i}\left(b_{i}^{*} ; M_{C}\right)=0
$$

Aggregate contributions for the charity are given by $\sum_{i \in \Omega} b_{i}^{*}$ and total public good provision by $G^{*}=\sum_{i \in \Omega} b_{i}^{*}-C\left(M_{c}\right)$, where $C\left(M_{c}\right)$ represents any expenditures-i.e., lottery prizes/gifts—accrued by a charity employing a particular mechanism. 


\section{A. Contribution Decisions and the Choice of Fund-raising Mechanism}

In many fund-raising campaigns, charities place importance on both participation rates and aggregate contribution levels. As such, it is important to examine individual participation rates in conjunction with aggregate contribution levels. We therefore analyze how the current choice of fund-raising mechanism $M_{c}$ impacts the left-hand sides of equations (2) and (3). We highlight three distinct channels through which the choice of a particular fund-raising mechanism can influence such decisions.

First, recall that we allow numeraire consumption $y_{i}\left(b_{i} ; M_{C}\right)$ to depend on the private monetary/consumption benefits $R_{i}\left(b_{i} ; M_{C}\right)$ conveyed by participation in a fundraising drive. Fund-raisers can thus influence numeraire consumption by selecting mechanisms such as charitable lotteries or donor gifts that provide a direct link between private benefits and contribution decisions. This would lead to gains on both the intensive and extensive margins - i.e., changes in conditions (2) and (3), respectively.

Second, the (expected) utility from the public good, $\mu_{i}\left(M_{c}, M_{p}\right) h_{i}(G)$, may be increased by announcing seed money donations, lottery prizes, or providing gifts to potential donors. If so, then we would expect such mechanisms to induce greater aggregate contribution levels. As previously used fund-raising mechanisms $M_{p}$ may have altered the perceived credibility of the charity, however, we allow an interaction between historical and current mechanisms. ${ }^{8}$

\footnotetext{
${ }^{8}$ For example, the marginal effect of providing donor gifts on the perceived credibility of the charity may differ across households previously approached in a charitable lottery and those previously approached in a VCM (or those approached for the first time).
} 
Finally, the composite utility term $f_{i}(\bullet)$ may depend upon non-monetary factors, such as the characteristics of a solicitor in a door-to-door fund-raising drive or the appeal mode. Consonant with this notion, Landry et al. (2006) find that solicitor characteristics, such as female physical attractiveness, influence giving. Likewise, social pressures may be greater in door-to-door fund-raising efforts than in mail solicitations. If agents receive disutility from not giving, and such feelings are related to the extent actions are observed by others (such as an expecting solicitor), then the appeal mode might have important effects on giving.

B. Warm-list vs. cold- list

Fund-raising strategists typically rank building and maintaining a "donor development pyramid" as the most important aspect of a successful long-term fundraising effort. While we are unable to find any clean empirical evidence that quantifies the value of a warm-list, our model highlights factors important in measuring the value of a warm-list agent. We partition the set $\Omega$ of agents into two types: (i) individuals who have never given to the charity, ( $\Omega^{C L}$, cold list) and (ii) previous givers to the charity ( $\Omega^{W L}$, warm-list):

$$
\Omega=\Omega^{W L} \cup \Omega^{C L}
$$

The set of cold-list agents, $\Omega^{C L}$, will contain some agents who elect to contribute to the charity (reflecting characteristics similar to an agent drawn from the warm-list) and some who do not contribute to the charity.

Under our model, those who have contributed in a prior campaign reveal either a high marginal valuation for the public good or a high realization of the composite utility term-i.e., a large warm glow or a distaste for not giving. Ceteris paribus, we would 
thus expect that warm-list households are more likely to contribute and provide larger donations than a randomly approached household. However, the economic value of a warm-list depends on how the marginal donor was acquired, which will influence their propensity to give in future campaigns.

For example, as noted in Landry et al. (2006), both lottery incentives and the attractiveness of female solicitors can be used to elicit contributions from extra-marginal donors. Yet, these two effects work through entirely different channels in our model. Charitable lotteries alter consumption utility and may serve to signal charitable quality. In contrast, beauty works solely via the instantaneous realization of the composite utility term. As such, the long-run impact of these mechanisms for the marginal donor could differ substantially.

As a thought experiment, consider the marginal donor who contributed previously to a physically attractive solicitor in a VCM. If such an agent is approached in a followup campaign by a solicitor of average attractiveness in a similar VCM, the realization of the composite utility term would be lower. Ceteris paribus, we would therefore expect a weakly lower contribution from such an agent. Alternatively, if this marginal donor was attracted via a lottery incentive, future contributions might remain high if the lottery sent an important quality signal that is durable; on the other hand, removing the lottery incentive might lower contributions because ceteris paribus it reduces consumption utility and could undermine prior quality signals.

\section{Experimental Design}

We designed a door-to-door fund-raising drive and a parallel mail solicitation to explore various aspects of the theoretical model. In each appeal mode, we use three basic 
treatments—a VCM, a small gift treatment, and a large gift treatment. ${ }^{9}$ We begin with a summary of the original Landry et al. (2006) design, and proceed to our door-to-door and mail solicitation field experiments.

\section{A. Precursors}

The Center for Natural Hazards Research at ECU was authorized to begin operations in the fall of 2004 by the North Carolina state government. The Hazard Center was founded in response to the widespread devastation in eastern North Carolina caused by hurricanes Dennis and Floyd, and designed to provide support and coordination for research on natural hazard risks.

The Hazard Center conducted an initial capital campaign in the Fall of 2004. As reported in Landry et al. (2006), this initial campaign was a completely randomized design that randomized households into various treatments. The experimental treatments were conducted on four weekends between October 2nd and November 13th, 2004. Their design resulted in a sample of 4833 households approached-1186 in a VCM treatment, 1282 in a seed money treatment, and 2356 in a lottery treatment. Of the households approached, a total of 1755 answered the door and spoke to a solicitor, and 522 made a contribution to the Hazard Center.

Importantly, we have data detailing the manner in which the households were initially approached along with the size of their gift. Further, as explained below, there has been no subsequent contact with the donors until our second set of field treatments.

\footnotetext{
${ }^{9}$ Our gift treatments included both conditional and unconditional small and large gift treatments with various price points. Herein we pool these gift data into "small" and "large." While conditionality does matter in terms of levels of gifts, the treatment effects of interest in this study are not influenced by this distinction. Hence, for parsimony we pool the data. We direct the reader to the supplementary appendix on the $A E R$ website for results examining the data split along conditional and unconditional treatments.
} 
In this new set of field treatments, we approach households that have given in the past and households that have never given, randomizing them into one of the three door-todoor or mail solicitation treatments. ${ }^{10}$

Before proceeding, we should note that the mission of the Hazard Center-to provide support and coordination for research on natural hazard risk-is of importance when interpreting our results. It is well understood amongst economists that individuals are more generous in the wake of emergency situations (see, e.g., Christopher Douty, 1972; Louis De Alessi, 1975; Jack Hirshleifer, 1987). Although the initial capital campaign for the Hazard Center was conducted nearly five years after Hurricanes Floyd and Dennis devastated eastern North Carolina in 1999, it is possible that some of our initial donors may have given in response to the memory of these events. Given that the long-term effects of such events on donor behavior are unknown, there may be added noise when extrapolating results on dynamics from our setting to charitable fund-raising in general. However, it is important to note that these past events should not correlate with any of our treatments.

\section{B. Door-to-Door Fund-raiser}

In each of our three door-to-door treatments, households in predetermined neighborhood blocks in Pitt County, North Carolina were approached by a paid solicitor and asked if they would like to make a contribution. The neighborhood blocks were selected to provide a representative sample of two distinct household types in each of the

\footnotetext{
${ }^{10}$ To increase the number of warm-list households, we pool data from Landry et al. (2006) with that from the gift exchange treatments in Uri Gneezy and List (2006). Solicitors in Gneezy and List (2006) spoke with 645 households in a lottery treatment and elicited contributions from 315 (or 48.9\%) of these individuals. The sole difference across these two experiments is that solicitors in Gneezy and List (2006) were informed that their wages would be doubled after arriving for their first day of work. Importantly, solicitors in the two studies were recruited and trained using the same protocol and every aspect of the interaction between solicitor and potential donor was identical.
} 
three treatments: (i) households that contributed to the Hazard Center in the first fundraising effort and (ii) households that have never contributed. ${ }^{11}$

Households that answered the door were provided an informational brochure detailing the activities of the Hazard Center since its inception in 2004 and read a fixed script that outlined the reason for the solicitor's visit. The script included a brief introduction that informed the resident of who the solicitors were, the purpose of their visit, a two-sentence summary of the non-profit organization, and a description of the gift (when applicable). Copies of the informational brochure and solicitation script are provided in Appendix 1.

Across all treatments, potential donors were informed that proceeds raised in the campaign would be used to fund research that benefits Pitt County and the surrounding area. In the small gift treatment, potential donors were provided a bookmark containing the logo of either the Hazard Center or ECU as a gift from the Hazard Center. In the large gift treatment, potential donors were provided a copy of the book Freakonomics as a gift from the Hazard Center. While these two goods might not be in exactly the same dimension (i.e., same gift but larger, as in Armin Falk, 2007), they are both related to an academic endeavor; and given the thickness of the book market for best sellers several bookmarks could be had for one Freakonomics book.

Table 1 summarizes the door-to-door portion of the experimental design. The experimental treatments were conducted between April $21^{\text {st }}$ and June $24^{\text {th }}$, 2006 with six sessions conducted between 9am and 5pm on Saturday and another five sessions

\footnotetext{
${ }^{11}$ Category (ii) household types can be more finely split: (a) those that were visited in the first effort but elected not to contribute and (b) those that did not speak to a solicitor in the first fund-raising drive. Since the qualitative results do not change, we pool these household types but we note that empirical results more finely splitting the data can be found in the tabled results on the $A E R$ website.
} 
conducted on Wednesday and Thursday evenings between 5pm and 8pm. Our design resulted in a sample of 4186 total households approached — 878 in the VCM, 1148 in the small gift, and 1142 in the large gift. ${ }^{12}$ Of the households approached, 1039 answered the door and spoke to a solicitor, and 277 made a contribution to the Hazard Center. Of the households that answered the door, 151 were warm-list households that contributed to the Hazard Center in 2004 and 888 were cold-list households that were not approached (or chose not to contribute to the Hazard Center) in the earlier door-to-door campaign.

\section{Recruiting and Training of Solicitors}

As Table 1 reveals, we employed a within-solicitor design using a total of thirtytwo unique solicitors. Of the thirty-two solicitors employed in our experiment, nineteen participated in the VCM treatment, twenty-four participated in the small gift treatment, and sixteen participated in the large gift treatment. ${ }^{13}$ To control for possible order effects, solicitors were randomly assigned to treatments, and we were careful to run multiple treatments in every round of the experiment.

Each solicitor's experience followed four steps: (1) consideration of an invitation to work as a paid volunteer for the research center, (2) an in-person interview, (3) a training session, and (4) participation as a solicitor in the door-to-door campaign. ${ }^{14}$ Undergraduate solicitors were recruited from the student body at ECU via flyers posted around campus, announcements on a university electronic bulletin board, advertisements

\footnotetext{
${ }^{12}$ We approached a total of 274 warm-list households - 74 in the VCM, 98 in the small gift treatment, and 102 in the large gift treatment. We would have preferred a larger sample of such households and revisited many of those who did not answer the door. Unfortunately the costs of such efforts became prohibitive and we were unable to speak with approximately 45 percent of the targeted warm-list households.

${ }^{13}$ Twelve of our solicitors worked in a single treatment. Of the remaining twenty solicitors, thirteen participated in two of the treatments and seven participated in all three treatments.

${ }^{14}$ A portion of the experimental design write-up follows Landry et al. (2006) since recruitment and training was similar.
} 
in the local campus newspaper, and direct appeal to student groups and students enrolled in undergraduate economics courses. All potential solicitors were told that they would be paid \$10 per hour and would be expected to work multiple days. Interested solicitors were instructed to contact the Economics Department to schedule an interview.

Initial ten-minute interviews were conducted in private offices of the Economics Department faculty. Upon arrival to the interview, students completed an application form and a short survey questionnaire. ${ }^{15}$ Upon concluding the interview, every applicant was offered employment as a solicitor. Once hired, all solicitors attended a one-hour training session conducted by the same researcher. The training sessions provided the solicitor with background/historical information of the Hazard Center and reviewed the data collection procedures. Next, the trainer reviewed the solicitation script for the VCM treatment and explained the procedures for distributing gifts to potential donors. At the conclusion of the training session, the solicitors practiced the script for the VCM treatment in front of the trainer and other personnel in the Economics Department. When necessary, the trainer provided immediate feedback to the solicitor on ways in which the pitch could be improved.

\section{Further Solicitor Information: Rating Physical Appearance}

In the final step, we gathered one last piece of information. In the spirit of the procedures of Jeffrey Biddle and Daniel Hamermesh (1998), we derived measures of physical attractiveness for each solicitor. Digital photographs of each solicitor were randomly allocated into files that contained the pictures of three other solicitors and independently evaluated by 175 different observers—undergraduate students from a large

\footnotetext{
${ }^{15}$ The application form and survey questionnaire are identical to those employed in Landry et al. (2006).
} 
introductory-level economics course at the University of Maryland-College Park. Each observer evaluated twelve different photographs and was asked to place each photograph on a scale of (1) homely, extremely unattractive, to (10) model beautiful or handsome. Each rater's scores were normalized to yield a standardized scale (distributed as a standard normal) across different raters. To generate our final personal attractiveness measure, the standardized ratings for each solicitor were averaged over all evaluators.

Before proceeding to the mail solicitation discussion, we should highlight a few important design issues. First, as previously noted, in carrying out our door-to-door campaign we wished to solicit donors in a way that matched how fund-raisers carry out the task in the field. Second, in order to provide a formal, standardized appearance, solicitors were given an attractive ECU t-shirt and were instructed to wear khaki pants (or shorts) during their door-to-door solicitations. Third, each solicitor wore an identification badge that included his or her picture, name, and city solicitation permit number. Fourth, solicitors distributed an information brochure after introducing themselves to potential donors. Fifth, we randomly allocated solicitors across neighborhoods and treatment type, and solicitors remained in the same treatment throughout each given session. Sixth, households were randomized into treatments and we attempted to provide temporal variation in both solicitor characteristics as well as mechanism type.

Finally, to summarize, we have gathered a rich set of solicitor and household control variables. Not only do we have measures of several potentially relevant solicitor attributes (race, gender, and beauty), we also have gathered data on the households that our solicitors approached. After the interaction with the household, each solicitor 
completed data collection forms that included the estimated age, gender, and race of the potential contributor.

\section{E. Mail Solicitation}

To complement the door-to-door fund-raiser, we ran a parallel mail solicitation natural field experiment to provide a further test of the theoretical model. Similar to the door-to-door drive, we allocated a certain number of households to one of the several treatments. We were careful not to place a household in more than one treatment and each household was only contacted once-either in the door-to-door drive or the mail solicitation. Again, we examined behavior across the two household types: households that have and have not previously contributed to the Hazard Center.

In total, we mailed 6563 solicitation letters across our three treatments - 1837 in the VCM treatment, 3783 in the small gift treatment, and 943 in the large gift. Each mailing contained a copy of the informational brochure detailing the activities of the Hazard Center since its inception in 2004 and a solicitation letter. A copy of the solicitation letter is included in Appendix B. Previous donors accounted for approximately 8.5 percent of the sample (or 555 of the 6563 total letters mailed). In keeping with best fund-raising practices, we included a sentence in the solicitation letter for previous donors thanking them for their donation in 2004 and expressing our hope that they will continue their generosity.

It should be noted that in preparing the letters for the mail survey, we used the White Pages on-line to gather the name associated with a given address and were unable to find a listing for approximately 25.1 percent (1649 of 6563) of all households. Letters sent to such a household for were addressed to "Pitt County Resident". As none of these 
letters were returned with a donation, we restrict the sample to the 4914 households that received a personalized greeting - 1363 in the VCM, 2831 in the small gift treatment, and 720 in the large gift treatment. Of these 4914 households, 399 (or approximately 8.1 percent) are warm-list individuals.

\section{Experimental Results}

We begin with a discussion of the door-to-door fund-raising results and then summarize results from the mail solicitation.

\section{A. Door-to-Door Fund-raiser}

Table 2 presents summary statistics, including information on the success of the various treatments, as well as solicitor and household characteristics. Table 2 indicates, for example, that our solicitors approached 878 households in the VCM treatment, and spoke with 286 of these households, of which 21.3 percent (61 of 286) contributed to the Hazard Center. In total, we raised approximately $\$ 2602$ (or \$2.96 per solicitation) for the Hazard Center: \$543.40 in the VCM treatment (\$1.90 per solicitation), \$677 in the small gift treatment (\$1.82 per solicitation), and \$1361.40 in the large gift treatment (\$3.68 per solicitation).

The Golden Rule in fund-raising emphasizes that securing a warm-list is essential to long-term viability. While we cannot test this Golden Rule directly, to our best knowledge little formal evidence exists concerning whether, and to what extent, previous donors remain committed to the cause. Our data set is sufficiently rich to examine these issues by matching our new field experimental data with the data contained in Landry et al. (2006). A first result emerges:

Result 1: Warm-list households are more likely to give and provide larger average contributions per contact. 
Preliminary evidence for this result can be found in column 1 (second and third panels) of Table 2, which summarizes the contribution decisions of warm and cold list households. Table 2 indicates, for example, that our solicitors had a chance to speak with 40 warm-list households in the VCM treatment, of which 40 percent (16 of 40) contributed to the Hazard Center. This figure far exceeds the 18.3 percent giving rate among cold list agents. Furthermore, considering average contributions, a warm-list household in our VCM treatment gave $\$ 4.75$ whereas the average donation of a household that has never given was $\$ 1.44$. Figures 1 and 2 complement these insights by providing a graphical depiction of differences across household type. These figures highlight that both participation rates and average contributions are higher among previous donors.

Using solicitor specific average earnings per treatment as the unit of observation, we find that the $\$ 3.21$ difference in average donations between warm and cold-list households in the VCM is significant at the $\mathrm{p}<0.05$ level. When comparing differences in participation rates, we find that the approximate 20 percentage point difference is also statistically significant at the $\mathrm{p}<0.05$. To complement these unconditional statistical insights, we estimate a series of linear regression models that explicitly control for observable and unobservable differences across solicitors. Specifically, following Landry et al. (2006), we estimate a regression model of the amount contributed for each household that answered the door (including zero contributions) on dummy variables for our experimental treatments and other covariates: ${ }^{16}$

$$
L_{i j}=Z_{i j} \delta+X_{i j} \beta+\varepsilon_{i j}
$$

\footnotetext{
${ }^{16}$ Qualitative insights are similar if we use a Tobit specification or if we estimate a standard two-stage selection equation with the yes-no contribution decision modeled in the first stage and the dollars contributed in the second. We direct the reader to the $A E R$ website for these robustness tests.
} 
where $L_{i j}$ is the contribution level of the $j^{\text {th }}$ household to the $i^{\text {th }}$ solicitor, $Z$ is a vector of treatment group status indicators, and $X$ is a vector of other covariates - including observable characteristics of potential donors and donor-specific controls for warm- and cold-list households. To account for unobservable heterogeneities at the solicitor level, we include solicitor fixed effects.

To gain insights into the factors that influence the decision of households to contribute to the Hazard Center, we estimate a linear probability model of the contribution decision of households that answered the door:

$$
C_{i j}=Z_{i j} \delta+X_{i j} \beta+e_{i j} \text {, }
$$

where $C_{i j}$ equals unity if solicitor $i$ received a contribution from household $j$, and equals zero otherwise. We again include solicitor fixed effects.

These empirical estimates are contained in Model A of Tables 3 and 4. In terms of average contribution decisions, Model A in Table 3 provides insights consistent with our unconditional results: warm-list households contribute an average of \$1.29 more to the Hazard Center than a cold-list household, with this difference being significant at the $\mathrm{p}<0.05$ level. Model A in Table 4 reports that this effect is partly driven by increased participation: warm-list households are 13 percent more likely to contribute to the Hazard Center than a household approached for the first time.

Exploring this result a level deeper, leads to a second result:

Result 2: Differences in contribution patterns between warm and cold list households are only found in the VCM treatment-in the gift treatments previous donors and cold-list households behave similarly.

Evidence for this result is contained in Model B in Tables 3 and 4, which permits the warm-list effect to be heterogeneous across our gift and VCM treatments. For example, 
empirical estimates in Table 3 for Model B suggest that a warm-list household in our VCM treatment contributes $\$ 3.14$ more than a counterpart cold-list household with this difference significant at the $\mathrm{p}<0.05$ level. However, warm-list households in our gift treatments behave no differently than a household approached for the first time in the gift treatment: the $\$ 0.19$ (\$1.06) increase in contributions from warm-list households in our small (large) gift treatments is not significant at any meaningful level.

Further, our data suggest that warm-list households contribute more in the VCM than either gift treatment with the approximate \$2.88 difference between the VCM and small gift treatments significant at the $\mathrm{p}<0.05$ level. ${ }^{17}$ In contrast, cold-list counterparts contribute more in both gift treatments than in the VCM with the \$2.07 difference between the large gift and VCM treatments significant at the $\mathrm{p}<0.05$ level.

Model B in Table 4 reports similar differences for participation rates. For example, warm-list households in our VCM (small gift) treatment are approximately 19 percent (14 percent) more likely to contribute to the Hazard Center than a cold-list counterpart with both of these differences being statistically significant at the $\mathrm{p}<0.05$ level. Yet, there is no statistically significant difference in participation rates for warmand cold-list households in our large gift treatment nor is there a significant difference in participation rates for warm-list households across our VCM and gift treatments. In contrast, cold-list households are 14-17 percent more likely to contribute when approached in a gift treatment with these differences significant at the $\mathrm{p}<0.05$ level.

\footnotetext{
${ }^{17}$ The average contribution level of a warm-list household in the small gift (large gift) treatment is given by the sum of the coefficients for the overall model constant, the indicator for a small gift (large gift) treatment, and the indicator for a warm-list household in the small gift (large gift) treatment. The average contribution level of a warm-list household in the VCM is simply the sum of the overall model constant and the indicator for a warm-list household in the VCM treatment. For cold-list households, the marginal effect of a small (large) gift is simply given by the coefficient on the indicator for a small (large) gift treatment.
} 
Combined, these insights form a third result:

Result 3: Cold-list households are influenced by the presence of a gift, whereas previous donors are less influenced by gifts.

In sum, Results 2 and 3 suggest an important consideration for practitioners in the field when designing capital campaigns. Prior donors do not require added incentives to induce contributions; in fact, providing such incentives to warm-list households may actually crowd-out contributions. Figure 3 complements this insight by showing the current and prior donation amounts for warm-list households across our various treatments. The figure highlights an interesting pattern of behavior: households approached in our VCM contribute more than in the initial fundraising drive whereas those approached in a gift treatment contribute less than in the initial campaign. ${ }^{18}$

One interesting aspect of our data is that they suggest a potential conflict between intrinsic and extrinsic motives for giving—particularly for small incentives (gifts). For prior donors (perhaps intrinsically motivated individuals), there is a significant reduction in average contribution levels when provided with a small donor gift (see Bruno S. Frey and Felix Oberholzer-Gee, 1997; Uri Gneezy and Aldo Rustichini, 2000). In contrast, even small extrinsic incentives have a positive effect on those households who had never given.

\section{B. Long-Run Impacts of Mechanism Incentives}

The above results provide insights into why people initially give to charities, and what factors delineate warm and cold list solicitees. Yet, our data permit us to explore

\footnotetext{
${ }^{18}$ One aspect of our setting that deserves further investigation is how the presence of gifts is related to perceived charity overhead, and how the gift exacerbates or attenuates our treatment effect differences across warm and cold list agents. Little is known about these questions, but the evidence is mixed concerning the relationship between overhead ratios and giving rates (see, e.g., Woods Bowman, 2006, and the work of Richard Steinberg). This represents an interesting area of future research.
} 
deeper into specific variables that might influence why previous donors remain committed to the cause. A key insight in John Morgan (2000), Morgan and Martin Sefton (2000), and Landry et al. (2006) is the efficacy of lotteries as an instrument to raise funds for the provision of public goods. For example, Landry et al. (2006) find that charitable lotteries induce higher participation rates and greater average contribution levels than those observed in VCM treatments. Conceptually, charitable lotteries can induce a greater level of giving for at least two reasons: (i) the announcement of lottery prizes can signal the credibility of the charity via the signaling theories discussed above and/or (ii) the provision of lottery prizes change monetary incentives and may induce higher contribution rates. As these effects work through different channels in our model, the effect of removing lottery incentives on the marginal donor is ex ante ambiguous.

For instance, if the signaling story is mainly responsible for the increased participation rates observed in Landry et al. (2006), then the marginal donor will continue to give at rates higher than counterparts initially attracted by the VCM-provided that prior quality signals carry through to future campaigns. Alternatively, if the marginal donors were initially attracted by the lure of the lottery prize itself, or if prior quality signals are mitigated in future campaigns, then we would expect lower relative giving rates amongst these donor types upon removal of the lottery incentive. Such an empirical test is quite demanding of the data given that our fund-raising drives were separated by one and one-half years. Nevertheless, to provide a test of these competing explanations, we return to equations (5) and (6) and augment the models to yield a first result:

Result 4: Donors initially attracted by mechanisms that can signal charitable quality are weakly more loyal to the cause than donors attracted by a VCM. 
Empirical evidence for this result is contained in Model C in Tables 3 and 4 and the difference-in-differences estimates presented in Table 5. Results in Tables 3 and 4 suggest that even though the previous lottery treatment attracted considerably more donors than the VCM attracted, these donor types remain weakly more loyal to the cause: warm-list households that contributed in a prior lottery (VCM) treatment give average gifts that are approximately $\$ 1.57$ (\$0.65) greater than those observed at households approached for the first time. ${ }^{19}$

Further, in Table 4 we find that the probability of eliciting a contribution from a donor initially attracted by the lottery is 17 percent greater than a household approached for the first time, a difference that is more than three times larger than the 5 percent effect observed for those initially attracted by the VCM. Yet, neither this twelve percent difference in participation rates nor the $\$ 0.92$ difference in average contributions across donor types is statistically significant at conventional levels (however, the difference nearly reaches the $\mathrm{p}<0.10$ level of significance in Table 4). Importantly, for our purposes, results in Tables 3 and 4 reveal that there is little evidence suggesting that removing the lottery incentives has a negative impact on donor behavior.

A stronger test of whether lotteries signal charitable quality is to compare individual changes in donation levels for households originally approached in a VCM with those for households originally attracted by a lottery. In this spirit, we provide Table 5 which extends our analysis to consider the manner in which the donor was acquired. To construct the numbers in Table 5 we first compute the average

\footnotetext{
${ }^{19}$ Similar results emerge if we allow the lottery effect to differ for households from single- and multipleprize treatments - both participation rates and average donations are greater than those for households from a prior VCM. Given this result, it is important to note that there were no discernable differences in either participation rates or average contributions across lottery treatments in Landry et al. (2006).
} 
contributions in both the current and prior fund-raising efforts for two household types: (i) those who gave initially in a VCM and (ii) those who gave initially in a lottery treatment. We then compare the difference in these averages along with the differencein-differences. Figures in Table 5 can be read as follows: households originally approached in a lottery (VCM) treatment give $\$ 0.05$ less (\$2.00 less) on average in the current fund-raiser. The $\$ 1.95$ difference-in-differences estimate is statistically significant at the $\mathrm{p}<0.10$ level.

Together, these two insights combined with the lottery results in Landry et al. (2006) highlight the significant benefits from lotteries. For practitioners in the field, Result 4 is important since it provides support for a "double-dividend" when one uses charitable lotteries. The increased participation rates induced via charitable lotteries provides not only current benefits but also a larger warm-list that leads to greater contributions in future fund-raising drives.

\section{Long-Run Impacts of Non-Mechanism Incentives}

Having examined the impact of altering institutional factors on donor behavior, we now explore the effect of changing non-mechanism effects, such as solicitor appearance. Landry et al. (2006) provide insights which reveal that attractive females elicited greater rates of participation and average contributions than other solicitor types: a one standard deviation increase in female solicitor physical attractiveness is similar to that of the lottery incentive. As noted in our theoretical model, such factors effect contribution decisions via the realization of the composite utility term. Ceteris paribus we would thus expect such solicitor specific characteristics to have no lasting impact on behavior in future capital campaigns. Our data are sufficiently rich to allow us to explore 
this conjecture by systematically changing the physical characteristics-i.e., gender and physical appearance — of the solicitor approaching a household. In doing so, we report a next result:

Result 5: Donors initially attracted by non-mechanism factors do not remain loyal to the charitable cause.

To provide evidence for this result, we classify solicitors into two typesattractive white females and all other solicitors - and divide warm-list households into three groups; (i) those visited by the same solicitor type on both occasions, (ii) those visited in the original study by an attractive white female, and in the current study by some other solicitor type, and (iii) those visited in the current study by an attractive white female, and in the original study by some other solicitor type. Under this classification, households in group (ii) represent those for which we removed an important noninstitutional incentive and those in group (iii) represent those for which we have introduced a previously non-existent incentive-white female beauty.

Figure 4 illustrates the effect of changing beauty effects by summarizing average contributions in the current and prior fund-raising drives for warm-list households visited by two different solicitor types. The figure highlights an interesting pattern of behavior: removing the non-institutional beauty incentive leads to reduction in average contribution levels whereas introducing a non-institutional incentive generates an increase in average contributions. Pooled over all treatments, when we remove a pre-existing beauty incentive, households contribute approximately 27.6 percent less (\$3.30 versus $\$ 4.21$ ) than they did in the initial fund-raising drive. In contrast, when we introduce new beauty incentives, average contributions increase by approximately 36.2 percent ( $\$ 4.85$ versus 
\$3.56). As noted in Table 5, however, the $\$ 2.20$ difference-in-differences is not statistically significant at any meaningful level. ${ }^{20}$

Combined with insights garnered in Result 4, these data suggest a fundamental difference in the efficacy of institutional versus non-institutional factors: while both factors lead to increased participation rates and average donations in the short-run, only institutional factors influence contribution decisions in future fund-raising drives. Hence the manner in which previous donors are acquired is an important determinant of behavior in future campaigns. Consistent with the model, donors who are initially attracted by mechanisms that potentially signal charitable quality—i.e., charitable lotteries or the announcement of seed money—are more likely to remain loyal than those enticed by non-mechanism factors that operate via warm-glow (or the realization of our composite utility term).

\section{Mail Solicitation}

Comparing empirical results across the door-to-door and the mail solicitations allows us to provide a first, albeit rough, test of the importance of changing approaches within fund-raising drives and evaluating whether our findings translate across different appeal modes. Yet, we should take great care when interpreting these results both because of the small number of donators in the mail solicitation and the fact that many important variables change when moving from the door-to-door drive to the mail solicitation (e.g., the gift is present in the door-to-door conditional gift treatment, but not

\footnotetext{
${ }^{20}$ As noted in Table 5, similar insights emerge if we expand the analysis to consider changes in female beauty rather than restricting the sample to Caucasian females only. Consonant with results from Landry et al. (2006) such differences are less pronounced because the influence of beauty for minorities is less pronounced than for their Caucasian counterparts.
} 
in the mail campaign). In the end, we view the data patterns presented in this section as merely suggestive, and representing fertile areas for future research.

Table 6 presents summary statistics from our mail solicitation field experiment, which includes information on the success of the various treatments across all households pooled and the subset of warm-list households. Table 6 indicates, for example, that we sent 1363 letters in the VCM treatment and received donations from two (or 0.15 percent) of these households. ${ }^{21}$ In total, we raised $\$ 560$ (or approximately $\$ 0.11$ per solicitation) for the Hazard Center: \$125 in the VCM treatment, \$240 in the small gift treatment, and \$195 in the large gift treatment.

A striking feature of Table 6 is the substantial reduction in response rates and corresponding increase in conditional contribution levels relative to our door-to-door campaign. For example, in our VCM treatment only 0.15 percent of the 1363 households who received a letter made a contribution to the Hazard Center. In contrast, 21.3 percent of the 286 households contacted (and 6.94 percent of the 878 households approached) in a VCM in the door-to-door component of the experiment elected to donate to the Hazard Center. Examining conditional contributions, we observe the direct opposite: households in the mail study contributed nearly seven-fold more (\$62.50 versus $\$ 8.92$ ) than those approached door-to-door.

Combined, these data are in line with recent results from laboratory experiments, which suggest the important influence of the nature and extent of scrutiny on individual behavior. In the door-to-door drive, actions are directly observed by an expectant outsider-perhaps leading to increased participation amongst marginal agents for whom

\footnotetext{
${ }^{21}$ We restrict the sample to only those 4914 households that received a personalized greeting when analyzing the data.
} 
feelings of guilt (or the realization of composite utility) are enhanced during face to face interaction. In contrast, our mail solicitations provide individuals "moral wiggle room," as contribution decisions are made privately and are not directly observed by an expecting outsider. This makes it easier for the marginal agent to opt out of giving. Thus, we observe lower overall participation rates and higher conditional contribution levels in our mail study. In this regard, our results are consistent with recent laboratory evidence suggesting the importance of context on social preferences (see, e.g., Jason Dana et al., 2005; Edward Lazear et al., 2006). ${ }^{22}$

Having used a comparison of mail and door-to-door solicitations to highlight the importance of social pressures on donor behavior, we now examine whether insights regarding the loyalty of previous donors translates across appeal modes. In this spirit, consider the third and fourth panels of Table 6 which summarize contribution decisions in our mail solicitation by household type-warm or cold list. In total, we mailed personalized letters to 399 warm-list households and received contributions from six (or approximately 1.5 percent) of these individuals for an average donation of approximately $\$ 0.83$ per solicitation. In contrast, only 0.13 percent (6 of 4515) of the cold list households receiving a letter from the Hazard Center contributed in our mail campaign and the average gift amongst these households was $\$ 0.05$ per letter. While both of these differences are significant at the $\mathrm{p}<0.05$ level, the small number of donors across both household types precludes strong inference. ${ }^{23}$

\footnotetext{
${ }^{22}$ Of course, the door-to-door approach might also lower transactions costs and provide solicitees with a clearer "channel" to give, both of which would lead to a similar data pattern.

${ }^{23}$ Interestingly, every warm-list household that contributes in the mail campaign was originally approached in a charitable lottery. This suggests that, as in the door-to-door campaign, agents initially attracted via mechanisms that signal charitable quality are more likely to contribute and provide larger average gifts in future fund-raising drives.
} 


\section{Concluding Remarks}

Economists have only recently begun to explore the basics of charitable giving. Fundamental insights pertaining to why people give to certain causes, why they remain loyal, and why they compose their gifts in the temporal profiles observed remain beyond most theoretical models. This study seeks to make a modest advance by linking charitable contributions across separate field experiments over time. In doing so, we are able to explore the long-run dynamics of charitable fund-raising apart from the short-run substitution effects observed in previous fund-raising field experiments.

Empirical results emphasize not only the value of securing a warm list but also the critical importance of how fund-raisers secure initial contributions. Donors initially attracted via economic mechanisms are more loyal to the cause than those attracted via non-mechanism factors, such as solicitor physical attractiveness. Yet such loyalty is mitigated when prior donors are provided extrinsic incentives, such as a token gift. Together, these results begin to shed light on the question posed in the title of this study, of which we can supply a definitive "it depends." Our results suggest that a charity prefers a donor in hand to two in the bush when (i) they do not have access to donor gifts, (ii) the donor was initially attracted via an economic mechanism, and (iii) the approach minimizes variation in the non-institutional factors that influence composite (warm-glow) utility. Conversely, a charity prefers two donors in the bush when (i) they have access to donor gifts, (ii) the donor was initially attracted via a mechanism that runs through the composite utility term, and (iii) the approach introduces large changes in the noninstitutional factors underlying composite utility. 
From a methodological viewpoint, our study showcases the usefulness of moving beyond an experimental design that focuses on short run substitution effects. While the literature has learned a great deal from that approach, a complementary framework that explores both short-run and long-run treatment effects can potentially provide a deeper understanding of many economic issues that our theoretical models are built to describe. 


\section{References}

Andreoni, James. 1989. “Giving with Impure Altruism: Applications to Charity and Ricardian Equivalence,” Journal of Political Economy 97(6): 1147-1458.

-. 1990. "Impure Altruism, and Donations to Public Goods: A Theory of Warm-Glow Giving,” The Economic Journal, 100(401): 464-477.

—. 1998. "Toward a Theory of Charitable Fundraising," Journal of Political Economy, 106(6): 1186-1213.

—. 2006. “Philanthropy,” In Handbook of Giving, Reciprocity and Altruism, eds. S-C. Kolm and J. Mercier Ythier, 1201-1269, Amsterdam: North Holland.

Bowman, Woods. 2006. "Should Donors care About Overhead Costs? Do They Care? Nonprofit and Voluntary Sector Quarterly, 2006, 35(2): 288-310.

Biddle, Jeff, and Daniel Hamermesh. 1998. "Beauty, Productivity, and Discrimination: Lawyers’ Looks and Lucre,” Journal of Labor Economics, 16(1): 172-201.

Chen, Yan, Xin Li and Jeffrey K. Mackie-Mason. 2006. "Online Fundraising Mechanisms: A Field Experiment," Contributions to Economic Analysis and Policy, 5 (2). http://www.bepress.com/bejeap/contributions/vol5/iss2/art4.

Clotfelter, Charles T. 1985. Federal Tax Policy and Charitable Giving. Chicago: University of Chicago Press.

Dana, Jason, Roberto A. Weber, and Jason Xi Kuang. 2005. “Exploiting moral wiggle room: Experiments demonstrating an illusory preference for fairness,” Working paper, Carnegie Mellon University.

De Alessi, Louis. 1975. “Toward an Analysis of Post Disaster Cooperation,” American Economic Review, 65(1): 127-138. 
Douty, Christopher. 1972. "Disasters and Charity: Some Aspects of Cooperative Economic Behavior,” American Economic Review, 62(4): 580-590.

Falk, Armin. 2007. “Gift Exchange in the Field,” Econometrica, 75(5): 1501-1511.

Frey, Bruno S. and Felix Oberholzer-Gee. 1997. "The Cost of Price Incentives: An Empirical Analysis of Motivation Crowding Out,” American Economic Review, 87(4): 746-755.

Gneezy, Uri and John A. List. 2006. "Gift Exchange in Experimental Markets," Econometrica, 74(5): 1365-1384.

Gneezy, Uri and Aldo Rustichini. 2000. “Pay Enough or Don't Pay At All.” Quarterly Journal of Economics 115(3): 791-810.

Hirshleifer, Jack. 1987. Economic Behaviour in Adversity. Chicago: University of Chicago Press.

Karlan, Dean and John A. List. 2007. "Does Price Matter in Charitable Giving? Evidence from a Large-Scale Natural Field Experiment,” American Economic Review, 97(5): 1774-1793.

Landry, Craig, Andreas Lange, John A. List, Michael Price, and Nicholas G. Rupp. 2006. "Toward an Understanding of the Economics of Charity: Evidence from a Field Experiment,” Quarterly Journal of Economics, 121(2): 747-782.

Lange, Andreas, John A. List, and Michael Price. 2007. "Using Lotteries to Finance Public Goods: Theory and Experimental Evidence,” International Economic Review, 48(3): 901-927.

Lazear, Edward, Ulrike Malmendier, and Roberto Weber. 2006. “Sorting in Experiments with Application to Social Preferences,” NBER Working Paper No. 12041. 
Levitt, Steven D. and John A. List. 2007. "What Do Laboratory Experiments Measuring Social Preferences Reveal About the Real World?," Journal of Economic Perspectives, 21(2): 153-174.

List, John A. and David Lucking-Reiley. 2002. "Effects of Seed Money and Refunds on Charitable Giving: Experimental Evidence from a University Capital Campaign,” Journal of Political Economy, 110(1): 215-233.

Meier, Stephan. 2007. "Do Subsidies Increase Charitable Giving in the Long-Run? Matching Donations in a Field Experiment," Journal of the European Economic Association, 5(6): 1203-1222.

Morgan, John. 2000. "Financing Public Goods by Means of Lotteries," Review of Economic Studies, 67(4): 761-784.

Morgan, John and Martin Sefton. 2000. "Funding Public Goods with Lotteries: Experimental Evidence,” Review of Economic Studies, 67(4): 785-810.

Peloza, John and Peirs Steel. 2005. “The Price Elasticities of Charitable Contributions: A Meta-Analysis,” Journal of Public Policy and Marketing, 24(2): 260-272.

Randolph, William. 1995. "Dynamic Income, Progressive Taxes, and the Timing of Charitable Contributions,” Journal of Political Economy, 103(4): 709-738.

Shang, Jen and Rachel Croson. 2007. "Field Experiments in Charitable Contribution: The Impact of Social Influence on the Voluntary Provision of Public Goods,” University of Texas at Dallas, Center for Behavioral and Experimental Economic Science Working Paper 07-08.

Vesterlund, Lise. 2003. “The Informational Value of Sequential Fundraising,” Journal of Public Economics, 87(3-4): 627-657. 
Table 1: Experimental Design - Door to Door Solicitation

\begin{tabular}{|c|c|c|c|}
\hline & $\begin{array}{c}\text { Voluntary } \\
\text { Contributions } \\
\text { Mechanism } \\
\end{array}$ & Small Gift & Large Gift \\
\hline $\begin{array}{l}\text { Session } 1 \\
\text { April } 22^{\text {nd }}\end{array}$ & $\begin{array}{c}6 \text { Solicitors } \\
168 \text { Visit } \\
69 \text { Home }\end{array}$ & $\begin{array}{c}7 \text { Solicitors } \\
201 \text { Visit } \\
90 \text { Home }\end{array}$ & \\
\hline $\begin{array}{l}\text { Session } 2 \\
\text { April } 29^{\text {th }}\end{array}$ & $\begin{array}{l}3 \text { Solicitors } \\
162 \text { Visit } \\
55 \text { Home }\end{array}$ & $\begin{array}{c}5 \text { Solicitors } \\
239 \text { Visit } \\
78 \text { Home }\end{array}$ & $\begin{array}{c}4 \text { Solicitors } \\
190 \text { Visit } \\
77 \text { Home }\end{array}$ \\
\hline $\begin{array}{l}\text { Session } 3 \\
\text { May } 3^{\text {rd }}-4^{\text {th }}\end{array}$ & $\begin{array}{c}4 \text { Solicitors } \\
181 \text { Visit } \\
71 \text { Home }\end{array}$ & & \\
\hline $\begin{array}{l}\text { Session } 4 \\
\text { May } 6^{\text {th }}\end{array}$ & & $\begin{array}{c}3 \text { Solicitors } \\
198 \text { Visit } \\
62 \text { Home }\end{array}$ & $\begin{array}{c}\text { Solicitors } \\
171 \text { Visit } \\
49 \text { Home }\end{array}$ \\
\hline $\begin{array}{l}\text { Session } 5 \\
\text { June } 7^{\text {th }}\end{array}$ & $\begin{array}{c}3 \text { Solicitors } \\
66 \text { Visit } \\
24 \text { Home } \\
\end{array}$ & $\begin{array}{c}3 \text { Solicitors } \\
92 \text { Visit } \\
28 \text { Home }\end{array}$ & $\begin{array}{c}3 \text { Solicitors } \\
74 \text { Visits } \\
40 \text { Home } \\
\end{array}$ \\
\hline $\begin{array}{l}\text { Session } 6 \\
\text { June } 10^{\text {th }}\end{array}$ & $\begin{array}{c}\text { Solicitors } \\
244 \text { Visit } \\
52 \text { Home } \\
\end{array}$ & $\begin{array}{l}2 \text { Solicitors* } \\
25 \text { Visit } \\
8 \text { Home }\end{array}$ & $\begin{array}{c}8 \text { Solicitors } \\
446 \text { Visit } \\
128 \text { Home }\end{array}$ \\
\hline $\begin{array}{l}\text { Session } 7 \\
\text { June } 15^{\text {th }}\end{array}$ & $\begin{array}{c}2 \text { Solicitors } \\
57 \text { Visit } \\
15 \text { Home }\end{array}$ & $\begin{array}{c}5 \text { Solicitors } \\
147 \text { Visit } \\
43 \text { Home }\end{array}$ & $\begin{array}{c}2 \text { Solicitors } \\
45 \text { Visit } \\
18 \text { Home }\end{array}$ \\
\hline $\begin{array}{l}\text { Session } 8 \\
\text { June } 17^{\text {th }}\end{array}$ & & $\begin{array}{c}4 \text { Solicitors } \\
143 \text { Visit } \\
35 \text { Home }\end{array}$ & $\begin{array}{c}3 \text { Solicitors } \\
86 \text { Visit } \\
22 \text { Home } \\
\end{array}$ \\
\hline $\begin{array}{l}\text { Session } 9 \\
\text { June } 22^{\text {nd }}\end{array}$ & & $\begin{array}{c}1 \text { Solicitor } \\
18 \text { Visit } \\
8 \text { Home }\end{array}$ & $\begin{array}{c}2 \text { Solicitors } \\
43 \text { Visit } \\
18 \text { Home } \\
\end{array}$ \\
\hline $\begin{array}{l}\text { Session } 10 \\
\text { June } 24^{\text {th }}\end{array}$ & & $\begin{array}{c}2 \text { Solicitors } \\
85 \text { Visit } \\
31 \text { Home }\end{array}$ & $\begin{array}{c}2 \text { Solicitors } \\
87 \text { Visit } \\
18 \text { Home }\end{array}$ \\
\hline
\end{tabular}

Note: Each cell represents one unique session in which we gathered data using one of the three treatments. For example, row 1, column 1, denotes that session one of the VCM treatment employed six solicitors that approached a total of 168 houses, of which 69 answered the door.

* In this treatment the solicitors only worked 2 hours before quitting due to illness. 
Table 2: Summary Statistics - Door-to-Door Solicitations

\begin{tabular}{|c|c|c|c|}
\hline & $\begin{array}{c}\text { Voluntary } \\
\text { Contributions } \\
\text { Mechanism } \\
\end{array}$ & Small Gift & Large Gift \\
\hline \multicolumn{4}{|l|}{ Contribution Decisions } \\
\hline \multicolumn{4}{|l|}{ All Data Pooled } \\
\hline Households (HH’s) Approached & 878 & 1148 & 1142 \\
\hline Total HH’s Home & 286 & 383 & 370 \\
\hline \% of HH's Donating & $21.3 \%$ & $27.4 \%$ & $30 \%$ \\
\hline Average Donation & $\$ 1.90$ & $\$ 1.82$ & $\$ 3.68$ \\
\hline Avg. Conditional Donation & $\$ 8.92$ & $\$ 6.65$ & $\$ 12.26$ \\
\hline \multicolumn{4}{|l|}{ Warm List Only } \\
\hline HH’s Approached & 74 & 98 & 102 \\
\hline Total HH’s Home & 40 & 60 & 51 \\
\hline \% of HH's Donating & $40 \%$ & $40 \%$ & $35.3 \%$ \\
\hline Average Donation & $\$ 4.75$ & $\$ 1.65$ & $\$ 4.37$ \\
\hline Avg. Conditional Donation & $\$ 11.88$ & $\$ 4.13$ & $\$ 12.38$ \\
\hline Avg. Previous Donation & $\$ 4.19$ & $\$ 3.28$ & $\$ 4.73$ \\
\hline \% from Previous VCM & $32.5 \%$ & $16.7 \%$ & $41.2 \%$ \\
\hline \% from Previous Lottery & $67.5 \%$ & $83.3 \%$ & $58.8 \%$ \\
\hline \multicolumn{4}{|l|}{ Cold List Only } \\
\hline HH’s Approached & 804 & 1050 & 1030 \\
\hline Total HH’s Home & 246 & 323 & 319 \\
\hline \% of HH's Donating & $18.3 \%$ & $25.1 \%$ & $29.2 \%$ \\
\hline Average Donation & $\$ 1.44$ & $\$ 1.86$ & $\$ 3.56$ \\
\hline Avg. Conditional Donation & $\$ 7.87$ & $\$ 7.40$ & $\$ 12.23$ \\
\hline \multicolumn{4}{|l|}{ Solicitor Characteristics } \\
\hline Total Number of Solicitors & 19 & 24 & 16 \\
\hline \% of White Male Solicitors & $10.5 \%$ & $16.7 \%$ & $12.5 \%$ \\
\hline Mean Beauty Rating & 0.01 & 0.006 & 0.02 \\
\hline \% of White Female Solicitors & $42.1 \%$ & $33.3 \%$ & $37.5 \%$ \\
\hline Mean Beauty Rating & 0.09 & 0.18 & 0.07 \\
\hline$\%$ of Minority Male Solicitors & $21.1 \%$ & $25 \%$ & $25 \%$ \\
\hline Mean Beauty Rating & 0.03 & -0.08 & -0.03 \\
\hline$\%$ of Minority Female Solicitors & $26.3 \%$ & $25 \%$ & $25 \%$ \\
\hline Mean Beauty Rating & 0.005 & -0.001 & -0.003 \\
\hline \multicolumn{4}{|l|}{ Household Characteristics } \\
\hline$\%$ of White Males & $45.5 \%$ & $42.5 \%$ & $39.2 \%$ \\
\hline$\%$ of White Females & $51.0 \%$ & $45.6 \%$ & $48.1 \%$ \\
\hline$\%$ of Minority Males & $1.0 \%$ & $6.9 \%$ & $6.2 \%$ \\
\hline \% of Minority Females & $2.5 \%$ & $5.0 \%$ & $6.5 \%$ \\
\hline Estimated Average Age & 44.13 & 44.25 & 41.95 \\
\hline
\end{tabular}

Note: Figures in the table represent summary statistics across the different treatments. 
Table 3: Average Donation per Household (HH) - Fixed Effects Regression Models

\begin{tabular}{|c|c|c|c|}
\hline & $\begin{array}{l}\text { Model A } \\
\text { \$’s Given }\end{array}$ & $\begin{array}{l}\text { Model B } \\
\text { \$’s Given }\end{array}$ & $\begin{array}{l}\text { Model C } \\
\text { \$’s Given }\end{array}$ \\
\hline Baseline - Cold List HH in VCM & $\begin{array}{l}1.83 * * \\
(0.45)\end{array}$ & $\begin{array}{l}1.56^{* *} \\
(0.47)\end{array}$ & $\begin{array}{l}1.84^{* *} \\
(0.45)\end{array}$ \\
\hline Indicator for a Small Gift Treatment & $\begin{array}{l}-0.41 \\
(0.61)\end{array}$ & $\begin{array}{c}0.06 \\
(0.66)\end{array}$ & $\begin{array}{l}-0.44 \\
(0.61)\end{array}$ \\
\hline Indicator for a Large Gift Treatment & $\begin{array}{l}1.79 * * \\
(0.64)\end{array}$ & $\begin{array}{l}2.07 * * \\
(0.68)\end{array}$ & $\begin{array}{l}1.80^{* *} \\
(0.64)\end{array}$ \\
\hline Indicator for a Warm List Household & $\begin{array}{l}1.29 * * \\
(0.59)\end{array}$ & & \\
\hline $\begin{array}{l}\text { Indicator for a Warm List } \mathrm{HH} \text { in the } \\
\text { VCM }\end{array}$ & & $\begin{array}{l}3.14 * * \\
(1.13)\end{array}$ & \\
\hline $\begin{array}{l}\text { Indicator for a Warm List HH in a } \\
\text { Small Gift Treatment }\end{array}$ & & $\begin{array}{c}0.19 \\
(0.95)\end{array}$ & \\
\hline $\begin{array}{l}\text { Indicator for a Warm List HH in a } \\
\text { Large Gift Treatment }\end{array}$ & & $\begin{array}{c}1.06 \\
(1.00)\end{array}$ & \\
\hline $\begin{array}{l}\text { Indicator for a Warm List } \mathrm{HH} \text { from a } \\
\text { Prior VCM }\end{array}$ & & & $\begin{array}{c}0.65 \\
(1.02)\end{array}$ \\
\hline $\begin{array}{l}\text { Indicator for a Warm List HH from a } \\
\text { Prior Lottery }\end{array}$ & & & $\begin{array}{l}1.57 * * \\
(0.69)\end{array}$ \\
\hline Solicitor Fixed Effects & Yes - 32 & Yes - 32 & Yes - 32 \\
\hline Observations & 1039 & 1039 & 1039 \\
\hline R-Squared & 0.02 & 0.03 & 0.02 \\
\hline
\end{tabular}

** Denotes statistical significance at the $\mathrm{p}<0.05$ level

Note: Cell entries provide parameter estimates for a fixed effects linear regression model of contribution levels (including the zeroes) for our experiment. Cell entries can be read as follows - average contribution levels in our small gift treatments are approximately \$0.41 less than those in our baseline VCM treatment. 
Table 4: Probability of Contributing - Fixed Effects Regression Model

\begin{tabular}{|c|c|c|c|}
\hline & $\begin{array}{l}\text { Model A } \\
\text { Pr (Give) }\end{array}$ & $\begin{array}{l}\text { Model B } \\
\text { Pr (Give) }\end{array}$ & $\begin{array}{l}\text { Model C } \\
\text { Pr (Give) }\end{array}$ \\
\hline Baseline - Cold List HH in VCM & $\begin{array}{l}0.15^{* *} \\
(0.03)\end{array}$ & $\begin{array}{l}0.14^{* *} \\
(0.03)\end{array}$ & $\begin{array}{l}0.15^{* *} \\
(0.03)\end{array}$ \\
\hline Indicator for a Small Gift Treatment & $\begin{array}{l}0.13^{* *} \\
(0.04)\end{array}$ & $\begin{array}{l}0.14^{* *} \\
(0.04)\end{array}$ & $\begin{array}{l}0.13^{* *} \\
(0.04)\end{array}$ \\
\hline Indicator for a Large Gift Treatment & $\begin{array}{l}0.15^{* *} \\
(0.04)\end{array}$ & $\begin{array}{l}0.17^{* *} \\
(0.04)\end{array}$ & $\begin{array}{l}0.15^{* *} \\
(0.04)\end{array}$ \\
\hline Indicator for a Warm List Household & $\begin{array}{l}0.13^{* *} \\
(0.04)\end{array}$ & & \\
\hline $\begin{array}{l}\text { Indicator for a Warm List } \mathrm{HH} \text { in the } \\
\text { VCM }\end{array}$ & & $\begin{array}{l}0.19 * * \\
(0.07)\end{array}$ & \\
\hline $\begin{array}{l}\text { Indicator for a Warm List HH in a } \\
\text { Small Gift Treatment }\end{array}$ & & $\begin{array}{l}0.14^{* *} \\
(0.06)\end{array}$ & \\
\hline $\begin{array}{l}\text { Indicator for a Warm List HH in a } \\
\text { Large Gift Treatment }\end{array}$ & & $\begin{array}{c}0.07 \\
(0.06) \\
\end{array}$ & \\
\hline $\begin{array}{l}\text { Indicator for a Warm List } \mathrm{HH} \text { from a } \\
\text { Prior VCM }\end{array}$ & & & $\begin{array}{c}0.05 \\
(0.07)\end{array}$ \\
\hline $\begin{array}{l}\text { Indicator for a Warm List HH from a } \\
\text { Prior Lottery }\end{array}$ & & & $\begin{array}{l}0.17 * * \\
(0.04)\end{array}$ \\
\hline Solicitor Fixed Effects & Yes - 32 & Yes - 32 & Yes -32 \\
\hline Observations & 1039 & 1039 & 1039 \\
\hline R-Squared & 0.02 & 0.02 & 0.02 \\
\hline
\end{tabular}

** Denotes statistical significance at the $\mathrm{p}<0.05$ level

Note: Cell entries provide parameter estimates for a fixed effects model estimating the dichotomous decision of whether or not a household made a contribution to the Hazards Center. Cell entries can be read as follows - agents in a small gift treatment are 13 percent more likely on average to contribute to the Hazards Center than in the VCM. 
Table 5: Changing Incentives in the Long-Run: Difference in Differences Estimates

\begin{tabular}{|l|c|c|c|}
\hline & Donation & Donation Prior & Difference \\
\hline Prior Lottery & 3.47 & 3.52 & -0.05 \\
$\mathrm{~N}=107$ & $(0.70)$ & $(0.37)$ & $(0.65)$ \\
\hline Prior VCM & 3.20 & 5.20 & -2.00 \\
$\mathrm{~N}=44$ & $(1.00)$ & $(0.74)$ & $(1.28)$ \\
\hline Diff-in-Diff & & & $1.95^{*}$ \\
& & & $(1.31)$ \\
\hline & & 4.21 & -0.91 \\
\hline Remove WF Beauty & 3.30 & $(0.65)$ & $(1.22)$ \\
$\mathrm{N}=33$ & $(1.08)$ & 3.56 & 1.29 \\
\hline Add WF Beauty & 4.85 & $(0.49)$ & $(1.96)$ \\
$\mathrm{N}=27$ & $(1.91)$ & & 2.20 \\
\hline Diff-in-Diff & & & $(2.24)$ \\
\hline & & 3.49 & -0.19 \\
\hline Remove Fem Beauty & 3.31 & $(0.38)$ & $(0.82)$ \\
$\mathrm{N}=78$ & $(0.75)$ & 4.36 & 0.03 \\
\hline Add Fem Beauty & 4.39 & $(0.63)$ & $(1.48)$ \\
$\mathrm{N}=38$ & $(1.49)$ & & 0.22 \\
\hline Diff-in-Diff & & & $(1.56)$ \\
\hline
\end{tabular}

* Denotes statistical significance at $\mathrm{p}<0.10$ level

Note: Cell entries provide average contribution levels for current and prior donation levels for warm-list households in our data with standard errors in parentheses. The final column provides the difference in contributions across the two campaigns including the associated difference-in-differences estimate. 
Table 6: Summary Statistics - Mail Solicitation

\begin{tabular}{|c|c|c|c|}
\hline & VCM Treatment & $\begin{array}{l}\text { Small Gift } \\
\text { Treatment }\end{array}$ & $\begin{array}{l}\text { Large Gift } \\
\text { Treatment }\end{array}$ \\
\hline \multicolumn{4}{|l|}{ All Data Pooled } \\
\hline Letters Mailed & 1837 & 3783 & 943 \\
\hline Total Letters Returned & 2 & 6 & 4 \\
\hline \% of HH's Donating & $0.11 \%$ & $0.15 \%$ & $0.42 \%$ \\
\hline Average Donation & $\$ 0.07$ & $\$ 0.06$ & $\$ 0.21$ \\
\hline Avg. Conditional Donation & $\$ 62.50$ & $\$ 40.00$ & $\$ 48.75$ \\
\hline \multicolumn{4}{|l|}{ All Addresses with Names } \\
\hline Letters Mailed & 1363 & 2831 & 720 \\
\hline Total Letters Returned & 2 & 6 & 4 \\
\hline \% of HH's Donating & $0.15 \%$ & $0.21 \%$ & $0.56 \%$ \\
\hline Average Donation & $\$ 0.09$ & $\$ 0.08$ & $\$ 0.27$ \\
\hline Avg. Conditional Donation & $\$ 62.50$ & $\$ 40.00$ & $\$ 48.75$ \\
\hline \multicolumn{4}{|l|}{ Cold List with Names } \\
\hline Letters Mailed & 1256 & 2596 & 663 \\
\hline Total Letters Returned & 1 & 3 & 2 \\
\hline \% of HH's Donating & $0.08 \%$ & 0.152 & $0.30 \%$ \\
\hline Average Donation & $\$ 0.08$ & $\$ 0.03$ & $\$ 0.08$ \\
\hline Avg. Conditional Donation & $\$ 100.00$ & $\$ 25.67$ & $\$ 25.00$ \\
\hline \multicolumn{4}{|l|}{ Warm List with Names } \\
\hline Letters Mailed & 107 & 235 & 57 \\
\hline Total Letters Returned & 1 & 3 & 2 \\
\hline \% of HH's Donating & $0.93 \%$ & $1.3 \%$ & $3.51 \%$ \\
\hline Average Donation & $\$ 0.24$ & $\$ 0.68$ & $\$ 2.54$ \\
\hline Avg. Conditional Donation & $\$ 25.00$ & $\$ 53.33$ & $\$ 72.50$ \\
\hline
\end{tabular}

Note: Figures in the table represent summary statistics across the various treatments. 
Figure 1: Average Contribution per Household (in dollars)

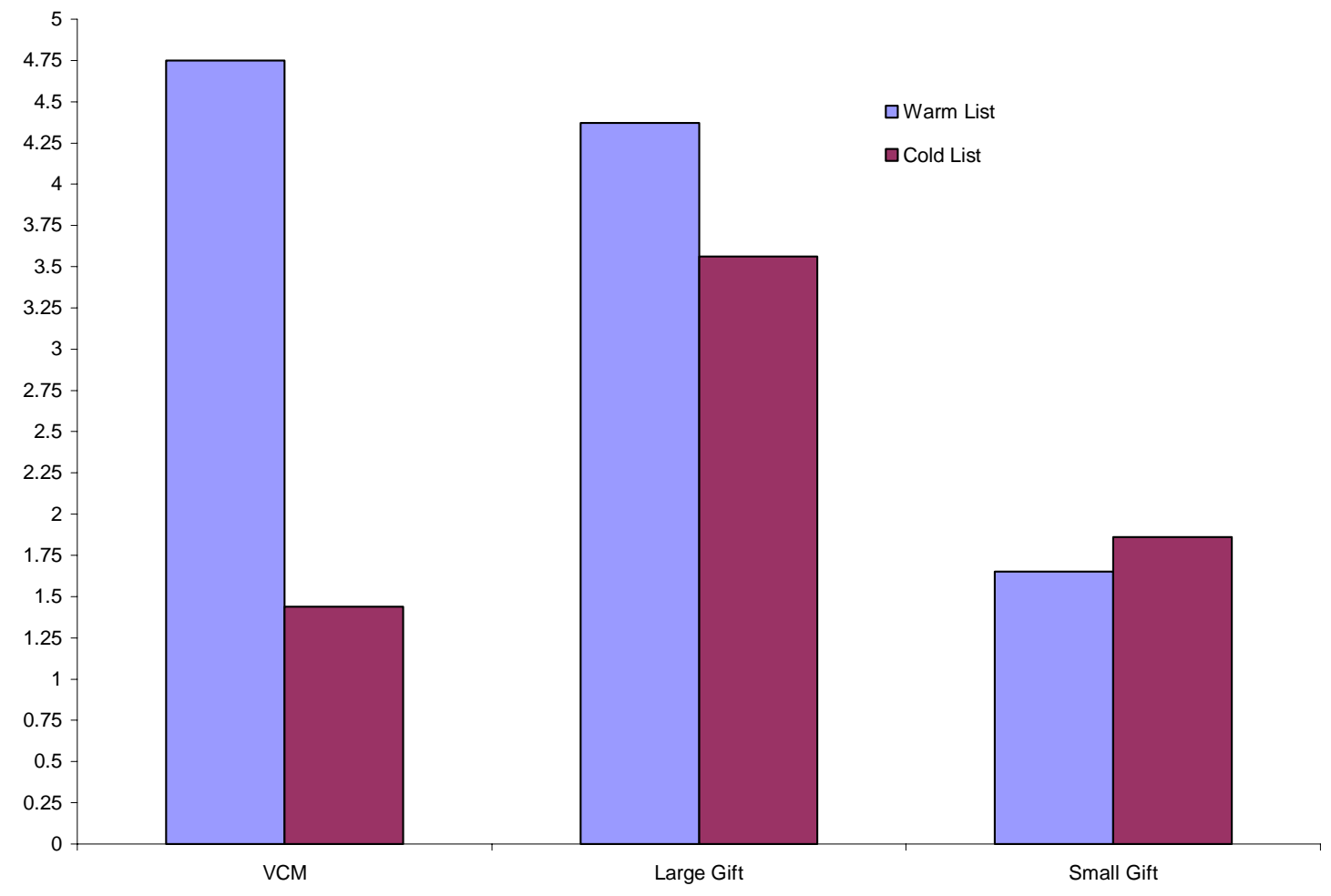

Figure 2: Percentage of Households Contributing

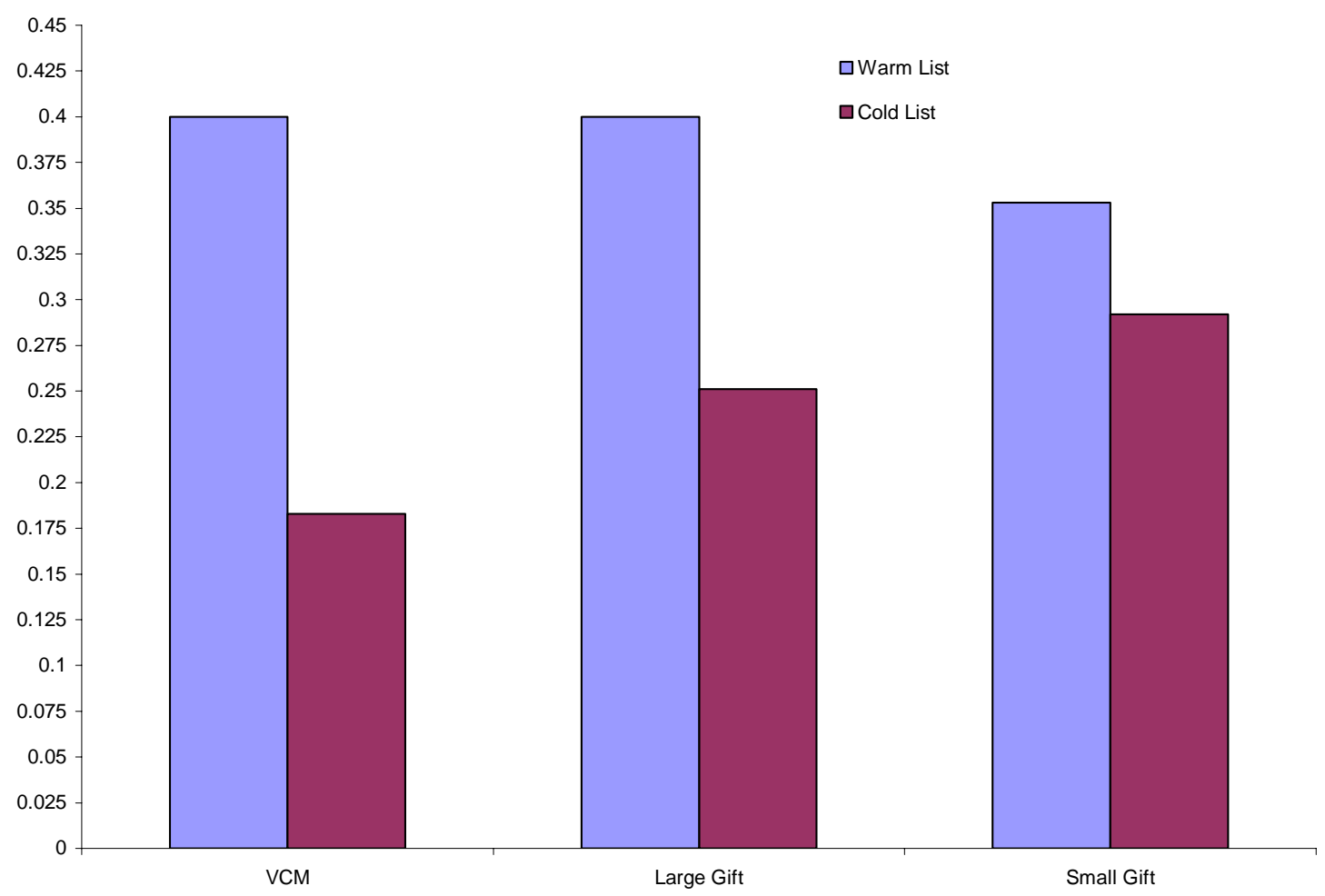


Figure 3: Current and Prior Donations - Warm List Households

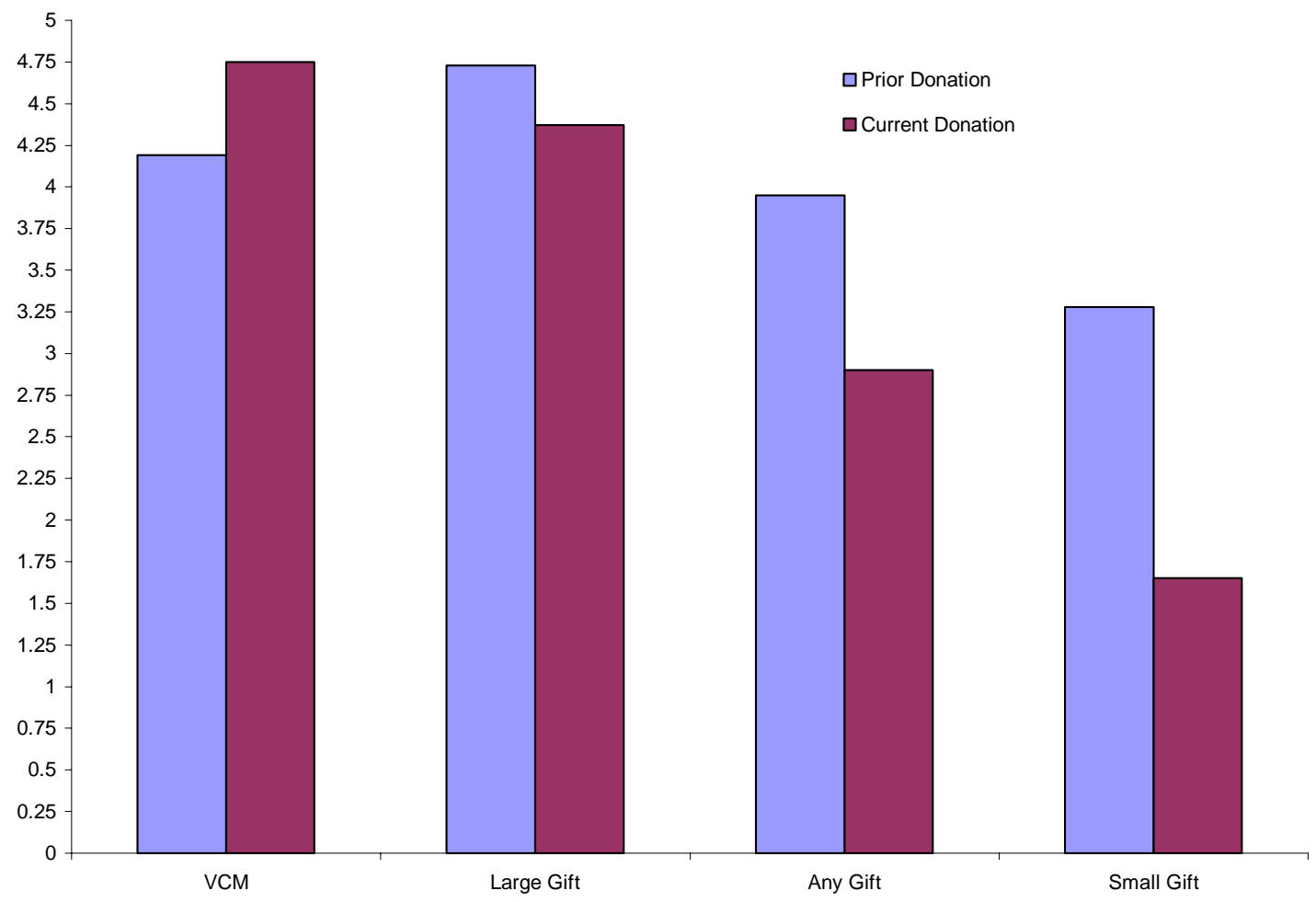

Figure 4: Changing Female Beauty and Changing Average Contribution Levels

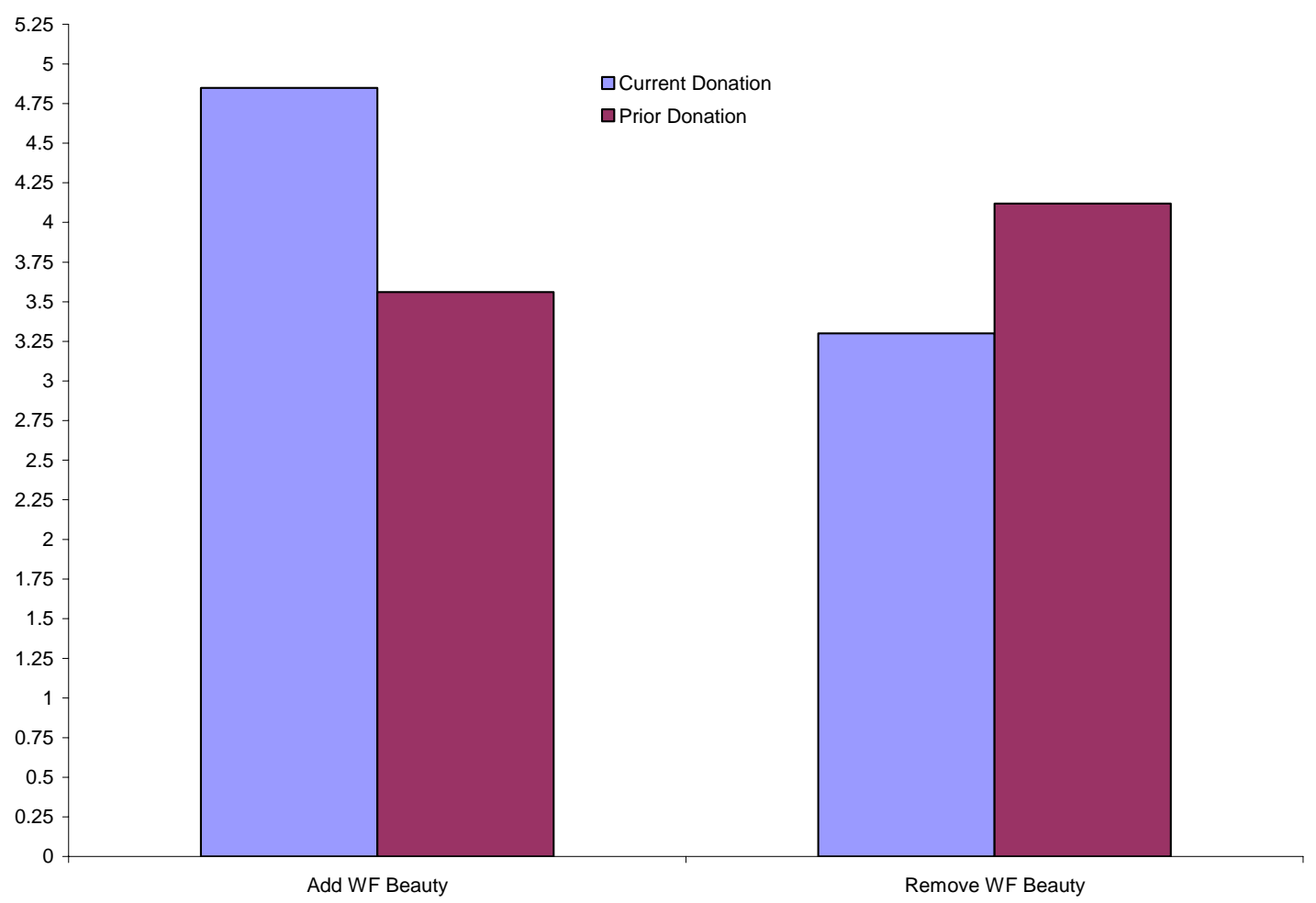




\section{Appendix A - Solicitation Scripts and Informational Brochure}

- Hi, my name is . I am an ECU student visiting Pitt County

households today on behalf of the ECU Center for Natural Hazards Research.

- The Hazard Center provides support and coordination for research on natural hazard risks, such as hurricanes, tornadoes, and flooding.

- Our newsletter describes recent research initiatives in the wake of Hurricane Katrina, and the Center's mission.

- The primary goal of the center is to reduce the loss of life and property damages due to severe weather events.

- We are collecting contributions today on behalf of the ECU Hazards Center.

(Unconditional Small Gift Treatment - Added Sentence)

As a gift from the Hazard Center, please accept this handsome bookmark.

(Conditional Small Gift Treatment - Added Sentence)

If you make a donation today, we will give you this handsome bookmark.

(Unconditional Large Gift - Added Sentence)

As a gift from the Hazard Center, please accept this copy of the Bestselling book FREAKONOMICS.

(Conditional Large Gift Treatment - Added Sentence)

If you make a donation today, we will give you a copy of the Bestselling book FREAKONOMICS

- The Center is a non-profit organization and these funds will be used to conduct research that benefits Pitt County and the surrounding area.

- Would you like to make a contribution today?

(If you receive a contribution, please write a receipt that includes their name and contribution amount. If the resident asks, contributions are tax deductible).

- If you have questions regarding the Center or want additional information, visit the web site listed in the newsletter.

Thank you. 


\section{ECU Center for Natural Hazards Research- Informational Brochure}

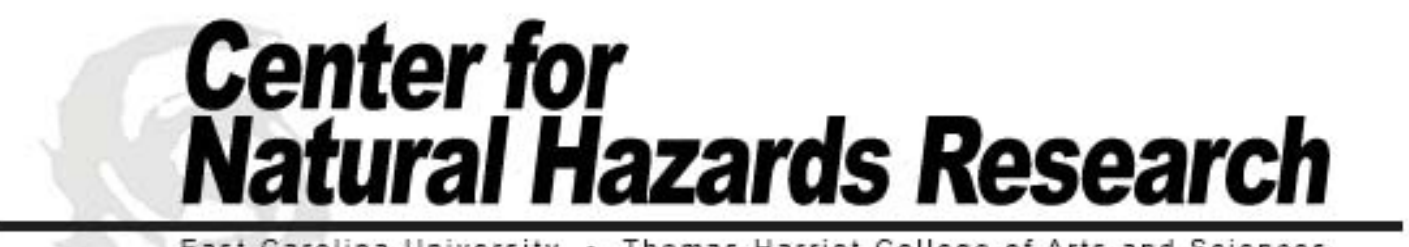

East Carolina University. Thomas Harriot College of Arts and Sciences

\section{Who We Are}

The Center for Natural Hazards Research (CNHR) at East Carolina University, founded in 2004, focuses on hucricane, tornado, flooding, and erosion hazards as they affect eastern North Carolina and the United States. The $\mathrm{CNHR}$ brings together researchers from various institutions and disciplines to identify methods to reduce potential losses of life, property, and infrastructuse ducing weather emergencies and to prowide support and coordination for research and outreach on natucal hazard risks.

Our areas of active research include the financial impacts of huecicanes and floods, the effectiveness of warning systems, how policy-makers should handle evacuations, and how households can protect themselves from natucal hazards. The CNHR. received grants from the National Science Foundation in January to study the effects of Hurricane Katrina on the gulf region and to investigate reconstruction efforts in New Orleans.

Like you, we have watched the tersible aftermath of natucal disasters in the United States and overseas over the past several months. Only minutes after the wave struck, news bulletins arrived to tell us of the horror and loss of life caused by the Indian Ocean Tsunnami on December 26, 2004. Victims of that disaster had vitually no warning of the killes wave. The tropical depression that became Hurvicane Katsina, on the other hand, was tracked for more than six days before it made landfall on the Lowisiana/Mississippi border. Scenarios projecting a major hurricane making landfall near New Orleans have been studied for the last twenty years! Yet, we watched in disbelief as news commentators showed us the destruction, suffering, and death that resulted from Katrina's waves, wind, and rain. Many of ws wondered how this could happen in the United States of America. If wre can help other countries and their people when a natucal disaster strikes, how is it that we are unable to take care of ous own' Katrina overwhelmed. us, demonstrating the inadequacy of evacuation plans and emergency response commanication netrorks. Relief efforts were painfully slow: Surely we can do better than this!

The CNHR plans to be part of the solution by engaging in high quality academic research and outreach that includes disseminating our research findings in a usable form to the community, not just to other researchers and academics. Our website will provide information about natual hazards that is useful to people in eastern North Carolina. We would like to know what kinds of information on natucal hazards you would find most valuable, so please visit us at www:ecu.edu/hazards to fill out our online feedback form

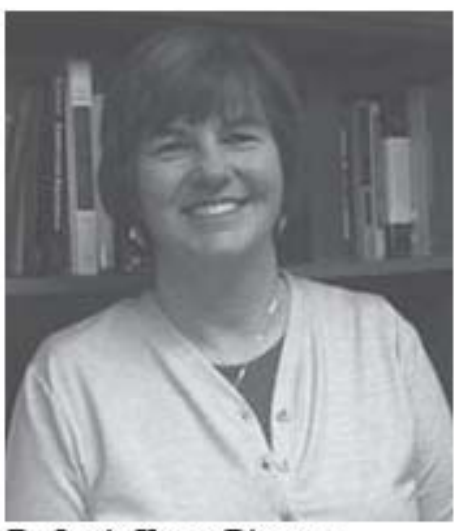

Dr. Jamie Kruse, Director Center for Natural Hazards Research East Carolina University

\section{Tell Us What You Think!}

The Center for Natural

Hazards Research at East

Carolina University plans to

undertake projects that focus

on natural hazards in Pitt

County, and we would like to

know what types of projects

you think are needed.

\section{Please visit our website at}

www.ecu.edu/hazards to tell

us your project ideas. To sub-

mit your ideas, simply click

the red "Feedback" button on

our homepage and fill out the

online form. 


\section{Recent CNHR Projects}

The "New" New Orleans: Evaluating Preferences for Rebuilding Plans after Hurricane Katrina. This grant from the National Science Foundation enables researchers from ECU's Economics, Planning, and Sociology departments to measure national attitudes toward rebuilding New Orleans and the commitment of federal monies to restoration. Researchers will assess what people want to preserve about New Orleans and to what extent citizens are willing to pay for it.

Collecting Economic Impact Data: Implications for Disaster Areas and Host Regions. With this grant from the National Science Foundation, researchers from ECU, Texas Tech University, Southern Mississippi-Long Beach, and Stephen F. Austin College will assess the economic impact of Katrina on the affected areas as well as the impact of evacuees on their host communities. North Carolina and Texas took in thousands of evacuees, and researchers will study whether federal funding available for the evacuees provides a positive economic impact to offset the drain on the host regions' resources.

Spatial, Environmental and Behavioral Determinants of Valuation of Coastal Erosion Risk. This ECU Research Development Grant enables researchers from ECU's Geography and Economics departments uncover risk attitudes and time discounting behavior of coastal property owners. Researchers will explore whether the public has adequately accounted for the inherent risks of these attractive coastal locations in their investment decisions.

\section{ecu logo}

Natural Disasters and Bank Performance. This Federal Deposit Insurance Corporation Center for Financial Research grant enabled researchers from ECU and Texas Tech University to examine the impact of wind damage on small and large banks in several tornado-prone areas and hurricane-prone areas.

\section{Determinants of Economic} Recovery in the Aftermath of a Hurricane Disaster. This National Science Foundation grant would enable researchers from ECU and Texas Tech University to examine the dynamic behavior of economic growth in areas affected by major or minor hurricanes in the years 1992 , 1999,2004 , and 2005.

Perceptions of Coastal Hazards: Decision Making Under Multidimensional Risk. This proposal, submitted to the National Science Foundation, would enable researchers from ECU's Economics and Geography departments to examine the perceptions and behavior of individuals in a natural decision environment that involves multiple risks that include a significant time dimension.

\section{Records of the 2005 Atlantic Hurricane Season}

- 26 Named Storms (previous record: 21 in 1933)

- 13 Hurricanes (previous record: 12 in 1969)

- Four major hurricanes hitting the U.S. (previous record: three in 2004)

- Three Category 5 Hurricanes (previous record: two in 1960 and 1961)

- Seven Tropical Storms before August 1 (previous record: five in 1997)

- Costliest Atlantic Season ( $\$ 107$ billion+) (previous record 2004, \$45 billion)

- Costliest Hurricane: Katrina ( $\$ 80$ billion+) (previous record Andrew, $\$ 26.5$ billion - 1992 dollars)

- Deadliest U.S. Hurricane since 1928: Katrina $(1,300+)$

- Strongest Hurricane in the Atlantic Basin: Wilma 882 mbar (previous record: Gilbert at 888 mbar

- Three of the six strongest hurricanes on record: Wilma 882 mbar $\left(1^{*}\right)$, Rita 897 mbar $\left(4^{\text {th }}\right)$, Katrina 902 mbar $\left(6^{\text {th }}\right)$

- July hurricane: Emily (155 mph top sustained winds) (previous record: Dennis (150 mph) in 2005; Hurricane \#1 (140 mph) in 1926

Storm records are from www.weather.com. For more records of the 2005 . Atlantic Harricane Season, wisit our website at www.erk.edu/ hagards.

\section{Help to Fund Research Projects in Pitt County!}

The Center for Natural Hazards Research at East Carolina

University is launching a fundraising initiative in Pitt County. If you receive a mail or door solicitation from one of our associates, keep in mind that any donations you make will be earmarked for projects in Pitt County only. Thank you! 


\section{$\underline{\text { Appendix B - Solicitation Letter Small Gift Treatment }}$}

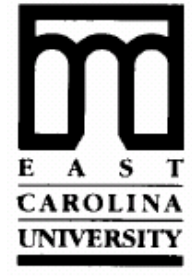

5-8-2006

Center for Natural Hazards Research

Thomas Harriot College of Arts \& Sciences

East Carolina University

Brewster A $117 \bullet$ Greenwille, NC 27858-4353

252-328-5718 office $\bullet 252-328-6743$ fax

1306 Evergreen

Greenville 27858, NC

Dear Pitt County resident

The East Carolina University Center for Natural Hazards Research is a non-profit organization that focuses on hurricane, tornado, flooding, and erosion hazards as they affect eastern North Carolina and the United States. The mission of the Center is to promote research and analysis that ultimately reduces the harm caused by forces of nature to life, business, and the environment.

In the wake of Hurricane Katrina, the Center spearheaded a number of research initiatives to examine how New Orleans should be rebuilt and the economic impact of evacuees on their host communities. In addition, we have begun to explore coastal hazards in eastern North Carolina and how they impact our citizens. The enclosed newsletter describes the mission of the Center and our recent research initiatives.

Together we can make a real difference for the residents of eastern North Carolina. But we need your assistance in this endeavor. We are appealing to residents of Pitt County to help support the Hazard Center by making a contribution that will help us expand our research program.

Your contribution can make a difference. An investment in the Center for Natural Hazards Research is an investment in the future of Pitt County and eastern North Carolina

As a token of our appreciation, we will send you a handsome bookmark featuring the logo of the North Carolina University a gift should you make a donation today.

All proceeds from this fund-raising drive will be used to fund research on Pitt and the surrounding Counties. You can offer feedback on what you would like to see the Center doing by visiting our website: www.ecu.edu/hazards.

Please consider making a contribution to the Hazard Center. Any amount would be appreciated. For your convenience, we have enclosed a postage paid return address envelope. Thank you.

Sincerely,

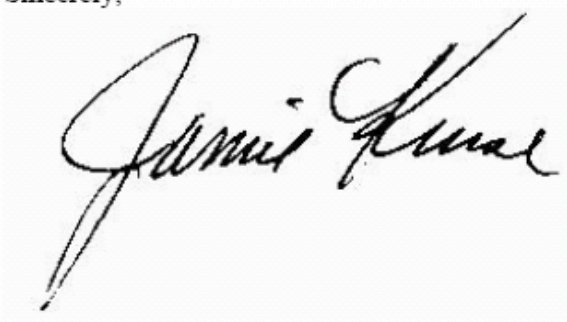

Jamie Kruse, $\mathrm{Ph} . \mathrm{D}$.

Center for Natural Hazards Research 